NIH dengue vaccine leaps into phase 3 studies p449

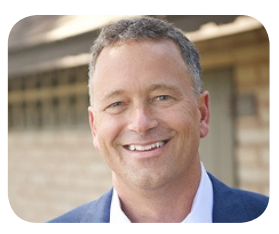

DNA tags speed up drug discovery

p450

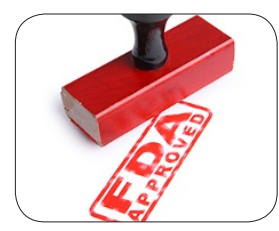

FDA approves first mAb biosimilar p454

\title{
Fetal tissue probe unsettles scientific community
}

On April 20, a special House committee held another hearing in an ongoing investigation on fetal tissue that is casting a pall on the biomedical community.

In the past few months, the subcommittee, called the Investigative Panel on Infant Lives, led by Marsha Blackburn, a Republican from Tennessee, has sent off a total of 15 subpoenas to scientific organizations, along with 40 letters, some of which request the names of researchers, technicians, and all other personnel involved with fetal tissue procurement and research in the past five years. In some cases, the investigative panel also requests copies of all emails exchanged between people involved with fetal tissue research, accounting records, and a wide range of other documents. If the recipients do not comply, they could be held in contempt of Congress.

These and other aggressive tactics have led House Democrats and scientists to call the investigation a smear campaign. They fear that the Panel intends to spook researchers into curbing their studies, to trigger more state laws that halt fetal tissue research, and to cast abortion in an unfavorable light.

However, Mike Reynard, a spokesperson for the Panel, says the requests are not intended to scare, but rather to help the members assess whether fetal tissue research is ethical, crucial, and conducted legally. "The point of the subpoenas is to gather information necessary for our investigators to fully understand exactly what is going on with the transactions between abortion businesses, procurement organizations, and other related entities," he says. "We also want to understand the necessity of the fetal tissue research."

Thus far, the subcommittee has issued subpoenas to, among others, an ethics review board involved with fetal tissue research, two medical supply companies, and the University of New Mexico.

The investigation follows last July's release of doctored videos that claimed to show Planned Parenthood clinics involved in the illegal sale of body parts. Since then, three congressional committees and 12 states have found zero evidence to indicate that Planned Parenthood profits from the sale of fetal tissue.

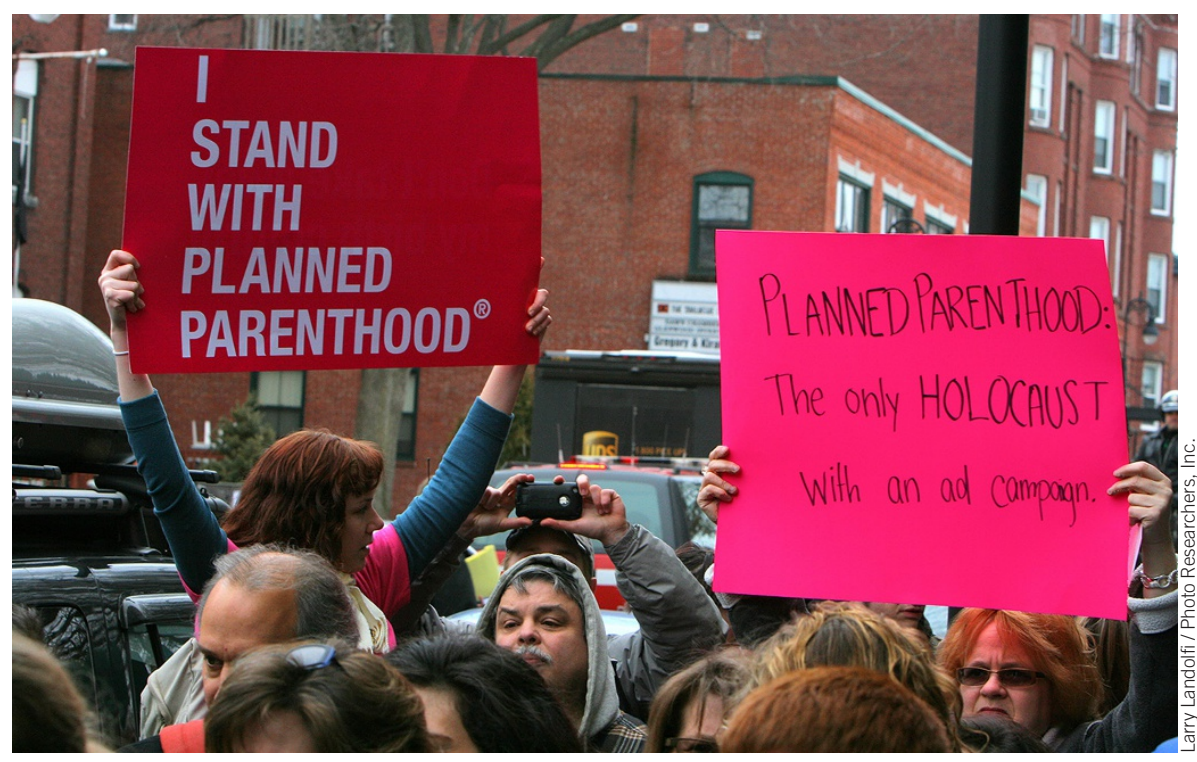

The uproar over fetal tissue uses began with action from anti-abortion groups against Planned Parenthood clinics.

In January, a Texas grand jury echoed that finding and instead indicted two people from the anti-abortion organization that produced the videos, the Center for Medical Progress. Nonetheless, Chairman Blackburn authored an op-ed April 6 in the National Review headlined "What Happened to 'Safe, Legal and Rare'? Abortion Today is about Profit, Profit, Profit."

"The chair has embarked on a partisan and dangerous witch hunt," said Representative Jan Schakowsky (D-Illinois) at a March 2 hearing of the Panel that focused on the ethics and necessity of fetal tissue research. Speaking at the hearing, Schakowsky recalled the words, "no more baby parts," uttered by the shooter who killed three people and injured nine others at a Planned Parenthood clinic in Colorado Springs, Colorado, in November 2015. The same type of inflammatory language was now being used by the Panel, she noted, in connection with fetal tissue research.

A spokesperson for the Panel says most names will be kept private, but there is no punishment to discourage their being leaked. Because of that possibility, scientists worry they could be targeted by anti-abortion extrem- ists. "We read news of deaths and attacks on abortion clinics, so one has to fear that someone misguided might put something in your mailbox, or do something to your children, and that has really caused a significant amount of anxiety," says Mike McCune, professor of medicine and chief of the Division of Experimental Medicine at the University of California, San Francisco, who studies fetal tissue in order to develop therapies to save infants with lethal congenital disorders and babies infected with HIV in utero.

McCune is one of the rare researchers who uses fetal tissue and agreed to speak on the record to Nature Biotechnology. Twenty others did not reply or declined to comment. One cancer researcher received hate mail after a conservative media website linked the investigator's name to fetal tissue research. In response, the floors of some researcher's laboratories are now permanently locked and de-identified, constraining the scholarly exchange of students, visitors, and ideas.

When a woman who has already elected to have an abortion decides to anonymously donate fetal tissue, it may go to researchers 
directly or to biomedical supply companies that process it-using it to generate cell lines, for example, and then selling those to investigators. These companies include Advanced Bioscience Resources (Alameda, California), StemExpress (Placerville, California), and the Ganogen Research Institute (Redwood City, California). The Panel has contacted these companies. On its website, Ganogen, Inc. writes, "While Ganogen has been subpoenaed by Congress in an act of political intimidation, we remain committed to continuing our research in our quest to save lives."

Because science has advanced over the past decade, the Panel is also asking why fetal tissue has not been replaced with newer tools, such as induced pluripotent stem cells harvested from adults. Fetal tissue cannot be paid for directly, so skeptics wonder whether scientists merely use it because it's cheap. "Are [scientists] acquiring tissue for their own convenience or because it's really needed for life-saving research?" the Panel spokesperson tells Nature
A hostile and unstable environment might drive researchers out of fields like infant medicine and pediatric HIV, which advance in part through fetal tissue research. fetal cells. Teva Pharmaceutical of Petah Tikva, Israel, relies on a fetal cell line named WI-38 to make the adenovirus flu vaccine given to US military personnel. That cell line is also used in the production of measles, rubella, rabies, hepatitis A, and chickenpox vaccines. According to the US National Institutes of Health, cell lines derived from fetal tissue continue to play an essential role in the creation of vaccines for certain diseases, including Ebola.

Goldstein and other researchers who work with fetal tissue say that it is often necessary to study a particular biological question-for example, how the Zika virus infects brain cells-in more than one cell type. If Congress were to shut down the use of fetal tissue cells, Goldstein says, progress toward treatments and cures would be delayed.

Still, some speakers at the March 2 hearing insisted the research was wrong, reasoning that one life should not be traded for another. McCune, who uses fetal tissue to figure out how babies with lethal genetic diseases might one day Biotechnology. $\mathrm{He}$ adds that they've heard mixed messages: "Some scientists claim to need it and others say there are alternatives." Indeed, a professor of radiology invited to testify at the Panel's March 2 hearing, radiology researcher Kathleen Schmainda from the Medical College of Wisconsin, argued that fetal tissue research is unethical and unnecessary.

However, Lawrence Goldstein, a neurobiologist at the University of California, San Diego, spoke on behalf of 60,000 life scientists and physicians belonging to the International Society for Stem Cell Research, the American Society for Cell Biology, and the Coalition for Life Sciences at the hearing, where he testified that fetal tissue research may continue to yield life-saving cures.

There is no one cell type best for research because each has specific properties, Goldstein said. Rather, the type of cell used depends on a researcher's goal. For instance, vaccine manufacture often relies on viruses replicating in cells, and certain viruses multiply very well in ing, Goldstein told Representative Sean Duffy (R-Wisconsin) that he acquires his fetal tissue from Neuralstem (Germantown, Maryland), and that they have assured him they conduct their business legally. "So that's it?" Duffy asked incredulously. "You haven't taken any further steps?"

Duffy also asked Goldstein some rather inflammatory, open-ended questions, such as, "Do you know how long it takes to carve out a little baby heart, or a little baby lung, or a little baby head?" Goldstein replied that he did not know because he was a researcher with a $\mathrm{PhD}$ and not a doctor.

"I don't think there's anything wrong with revisiting ethical debates, but I don't think that's what this is," says R. Alta Charo, a bioethics law professor from the University of Wisconsin-Madison who testified at the hearing. "It seems to be an excuse to milk some value out of the doctored videos so that the general public has the perception that there is something shady in the abortion industry linked to commercial interest." She adds, "That's a real problem if it leads to shutting down research we truly need."

That's already happening. In March, Florida passed legislation to prohibit the donation of aborted tissue. Similar bills that limit or halt research on fetal tissue from abortions have also been introduced in several states, including Indiana, North Dakota, South Dakota, Oklahoma, Ohio, Minnesota, and Wisconsin. And one planned trial on a therapy for wheelchair-using patients with multiple sclerosis has been put on hold due to a sudden freeze on fetal tissue donations. "We may be able to switch to embryonic stem cells in a few years," says an investigator on that trial, Steve Goldman, a neurologist at the University of Rochester Medical Center in Rochester, New York. "But it's a tragedy we cannot try this now. A few years is a big deal to an MS patient who is wheelchair bound-their health rapidly deteriorates at that stage, and they can die."

Even if no one is found guilty in the investigation, a hostile and unstable environment might drive researchers out of fields like infant medicine and pediatric HIV, which advance in part through fetal tissue research. "I can guarantee you that if a young scientist looks down the road and sees a shotgun, they will not gravitate in that direction," McCune says.

Amy Maxmen Berkeley, California 